\title{
Salinity decreases transpiration of sorghum plants
}

\author{
Miguel Julio Machado Guimarães ${ }^{1, *}$ (D), Welson Lima Simões ${ }^{2}$, Juliane Rafaele Alves Barros ${ }^{3}$ and \\ Lilia Gomes Willadino ${ }^{4}$ \\ ${ }^{1}$ Programa de Pós-Graduação em Engenharia Agrícola, Universidade Federal do Vale do São Francisco, Juazeiro, BA, Brazil., \\ ${ }^{2}$ Embrapa Semiárido, Petrolina, PE, Brazil., ${ }^{3}$ Programa de Pós-Graduação em Recursos Genéticos Vegetais, Universidade \\ Estadual da Bahia, Feira de Santana, Bahia, Brazil., and ${ }^{4}$ Departamento de Biologia, Universidade Federal Rural de Pernambuco, \\ Recife, PE, Brazil. \\ *Corresponding author: Email: mjmguimaraes@hotmail.com
}

(Received 24 April 2020; Revised 14 May 2020; Accepted 15 May 2020)

\begin{abstract}
Growing in a saline environment causes changes in important physiological processes that are directly related to plant growth and development. In this study we evaluated the effect of salinity on transpiration of sorghum plants in semi-arid conditions and found that the highest rates of transpiration were observed in the hottest hours of the day, between 10 a.m. and 3 p.m., with plants subjected to the saline environment having their transpiration reduced by up to $70 \%$ when compared to the non-saline environment. This behavior can be reflected in reductions in plant growth and development due to reduced water absorption by the roots, consequently causing an imbalance of nutrients in the plant due to low absorption rate and competition between nutrients and salts in the preferred routes of absorption in the roots.
\end{abstract}

Keywords: water consumption; semi-arid conditions; salinity; Sorghum bicolor (L.) Moench

\section{Introduction}

Salinity is one of the most severe environmental stresses and the responses given by plants are diverse. These are reflected in physiological variables (stomach conductance, rate of perspiration and photosynthesis) (Freire et al., 2014), biometrics (height, leaf area, biomass production) (Guimarães et al., 2019), biochemistry (antioxidant enzymes) (Barbosa et al., 2014). Sorghum bicolor (L.) Moench is a crop species that presents $\mathrm{C} 4$ mechanism, and is one of the most versatile and efficient species in terms of photosynthetic mechanism (Berenguer \& Faci, 2001). This contributes to its greater resistance to adverse conditions. The tolerance of plants to salinity is associated with the development of mechanisms that contribute to minimize salt stress. Theses mechanisms have different energy costs for the plants, which negatively affect plant gas exchange, and consequently plant growth and development (Hassanein et al., 2010).

\section{Objective}

The objective of the present study was to evaluate the influence of saline water irrigation on the transpiration of sorghum (Sorghum bicolor (L.) Moench) plants under semi-arid conditions.

\section{Methods}

The study was conducted in a controlled environment in the semi-arid region of Brazil. During the experiment period the average relative humidity was $48.72 \%$ and the temperature around $26.86^{\circ} \mathrm{C}$. The

\footnotetext{
(C) The Author(s), 2020. Published by Cambridge University Press. This is an Open Access article, distributed under the terms of the Creative Commons Attribution licence (http://creativecommons.org/licenses/by/4.0/), which permits unrestricted re-use, distribution, and reproduction in any medium, provided the original work is properly cited.
} 
maximum evapotranspiration observed was 7.28 , with an average of $6.03 \mathrm{~mm} \mathrm{day}^{-1}$. Sorghum seeds (Sorghum bicolor (L.) Moench), Ponta Negra variety, were seeded in 25 plastic pots of $20 \mathrm{dm}^{3}$, filled with medium-textured soil, totalizing five repetitions per treatment. The plants were submitted to irrigation with the following salinity levels: $0.0 ; 1.5 ; 3.0 ; 6.0$ and $12.0 \mathrm{dS} \mathrm{m}^{-1}$. For irrigation management, weight lysimeters were installed with an electronic data collection system that recorded the weight of the pots every 15 minutes. Irrigation was performed by applying a leaching fraction of $15 \%$ to prevent the accumulation of salts in the soil. At 60 days after seeding the total leaf area of the plants was determined. Transpiration was determined from the weight differences recorded in the weight lysimeters.

\section{Results}

There was a linear reduction of the total leaf area of the plants with an increase in the salinity of the water used for irrigation, which contributed to lower perspiration values of the plants submitted to the higher salinity levels. It was observed that specific transpiration (represented by the ratio of transpired water volume per square meter of leaf area) decreased with the increase in salinity (Fig. 1), evidencing the effect of salts on the gas exchange of sorghum plants. Plants submitted to higher salinity levels generally presented lower transpiration values at all times evaluated. The highest values of transpiration were observed in the range of 10 a.m. to 3 p.m. (Fig. 2), being in accordance with the climatic data of the region,
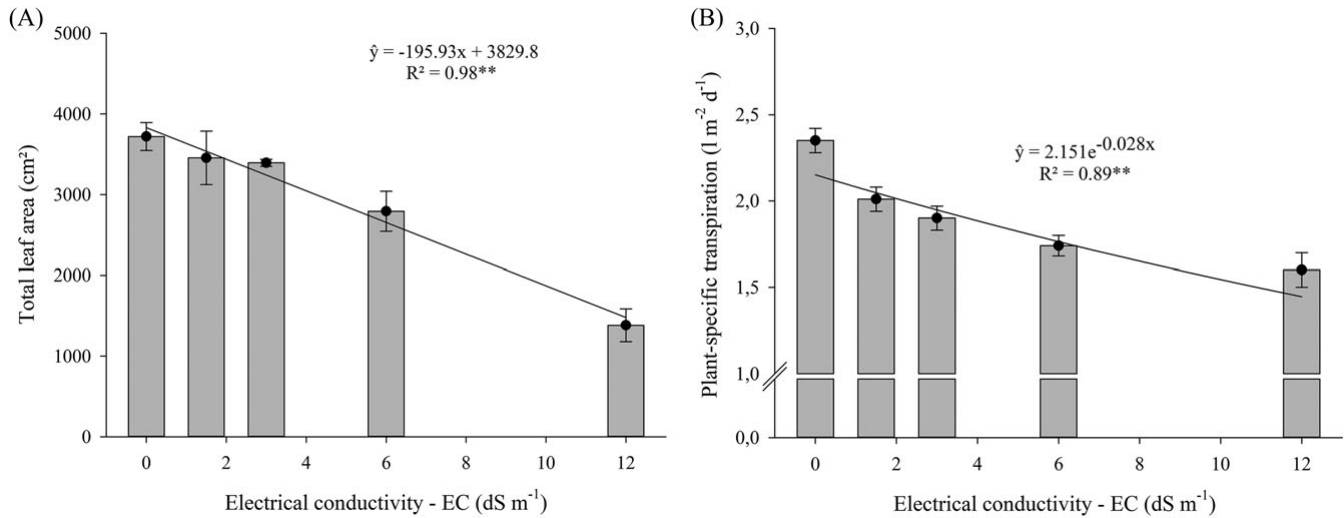

Figure 1. Total leaf area (A) and plant-specific transpiration (B) of sorghum submitted to salinity levels. Error bars with standard deviation. $\left(^{* \star}\right)$ Significant regression coefficient with $p<0.01$.

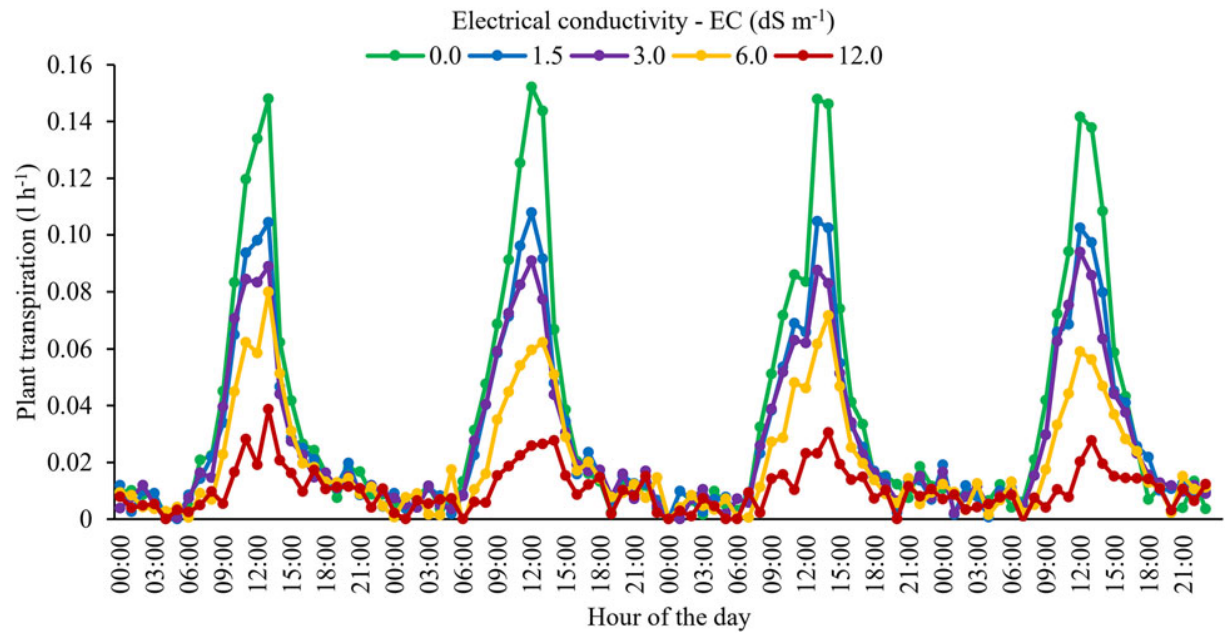

Figure 2. Daily variation of transpiration of sorghum submitted to salinity levels. 
which presents higher temperatures in the range that the highest transpiration was registered, considering that one of the main functions of transpiration is the regulation of plant temperature.

\section{Discussions}

Reductions in gas exchange of plants subjected to saline environments are associated with the osmotic effect on plant metabolism (Silva et al., 2013). Studies with fodder sorghum have shown that the continuous use of water with salinity above the threshold of the crop reduces the rate of transpiration due to partial closure of the stomata (Coelho et al., 2018). Liu et al. (2015) reported a direct influence of salinity on the water and photosynthetic relationships of sorghum leaves. Heidari (2009) reported that the potential for negative water in sorghum leaves affected by salt resulted in reduced transpiration of the evaluated plants, corroborating with the data presented in this study.

\section{Conclusions}

The present results indicate that the salinity of irrigation water has strong interference with transpiration of sorghum plants. The reductions in transpiration observed in this work may reflect in reductions in plant growth and development, since transpiration is a physiological process that encompasses the passage of water through the entire body of the plant, from its absorption at the roots to evaporation at the surface of the leaves through the stomata, having a direct relationship with the absorption and distribution of nutrients in the plant.

Acknowledgements. The authors would like to thank Embrapa Semiárido for their technical assistance.

Author Contributions. WLS and LGW conceived the study. MJMG conducted data collection, performed statistical analyses. MJMG and JRAB wrote the article.

Funding Information. This work was funded by the Foundation for the Support of Science and Technology of the State of Pernambuco - FACEPE on a scholarship (IBPG-1556-5.03/13), and National Council for Scientific and Technological Development $(\mathrm{CNPq})$ with the financial support.

Conflicts of Interest. All authors declare no conflicts of interest.

Data availability. The authors confirm that the data supporting the findings of this study are available within the article and/or its supplementary materials. If additional data is required, is available from the corresponding author, [MJMG], upon reasonable request.

Supplementary Materials. To view supplementary material for this article, please visit http://dx.doi.org/10.1017/exp.2020.22.

\section{References}

Barbosa, M. R., Silva, M. M. A., Willadino, L., Ulisses, C., \& Camara, T. R. (2014). Geração e desintoxicação enzimática de espécies reativas de oxigênio em plantas. Ciência Rural, 44, 453-460. doi:https://doi.org/10.1590/S0103-84782014000300011.

Berenguer, M. J., \& Faci, J. M. (2001). Sorghum (Sorghum bicolor L. Moench) yield compensation processes under different plant densities and variable water supply. European Journal of Agronomy, 15, 43-55. doi:https://doi.org/10.1016/S1161-0301 (01)00095-8.

Coelho, D. S., Simões, W. L., Salviano, A. M., Mesquita, A. C., \& Alberto, K. C. (2018). Gas exchange and organic solutes in forage sorghum genotypes grown under different salinity levels. Revista Brasileira de Engenharia Agrícola e Ambiental, 22 231-236. doi:https://doi.org/10.1590/1807-1929/agriambi.v22n4p231-236.

Freire, J. L. O., Dias, T. J., Cavalcante, L. J., Fernandes, P. D., \& Lima Neto, A. J. (2014). Rendimento quântico e trocas gasosas em maracujazeiro amarelo sob salinidade hídrica, biofertilização e cobertura morta. Revista Ciência Agronômica, 45, 82-91. doi:https://doi.org/10.1590/S1806-66902014000100011.

Guimarães, M. J. M., Simões, W. L., Oliveira, A. R., Araújo, G. G. L., Silva, E. F. F., \& Willadino, L. G. (2019). Biometrics and grain yield of sorghum varieties irrigated with salt water. Revista Brasileira de Engenharia Agrícola e Ambiental, 23, $285-290$. doi:https://doi.org/10.1590/1807-1929/agriambi.v23n4p285-290.

Hassanein, M. S., Ahmed, A. G., \& Zaki, N. M. (2010). Growth and productivity of some sorghum cultivars under saline soil condition. Journal of Applied Sciences Research, 6, 1603-1611. 
Heidari, M. (2009). Antioxidant activity and osmolyte concentration of sorghum (Sorghum bicolor) and wheat (Triticum aestivum) genotypes under salinity stress. Asian Journal of Plant Sciences, 8, 240-224. doi:https://doi.org/10.3923/ ajps.2009.240.244.

Liu, P., Yin, L., Wang, S., Zhang, M., Deng, X., Zhang, S., \& Tanaka, K. (2015). Enhanced root hydraulic conductance by aquaporin regulation accounts for silicon alleviated salt-induced osmotic stress in Sorghum bicolor L. Environmental and Experimental Botany, 111, 42-51. doi:https://doi.org/10.1016/j.envexpbot.2014.10.006.

Silva, F. L. B., Lacerda, C. F., Neves, A. L. R., Sousa, G. G., Sousa, C. H. C., \& Feerira, F. J. (2013). Irrigação com águas salinas e uso de biofertilizante bovino nas trocas gasosas e produtividade de feijão-de-corda. Irriga, 18, 304-317. doi:https://doi. org/10.15809/irriga.2013v18n2p304.

Cite this article: Guimarães MJM, Simões WL, Barros JRA, Willadino LG (2020). Salinity decreases transpiration of sorghum plants Experimental Results, 1, e14, 1-8. https://doi.org/10.1017/exp.2020.22 


\section{Peer Reviews}

\section{Reviewing editor: Dr. Richard Erickson}

US Geological Survey, Upper Midwest Environmental Sciences Center, 2630 Fanta Reed Rd, La Crosse, Wisconsin, United States, 54603

This article has been accepted because it is deemed to be scientifically sound, has the correct controls, has appropriate methodology and is statistically valid, and met required revisions.

doi:10.1017/exp.2020.22.pr1

\section{Review 1: Salinity decreases transpiration of sorghum plants}

Reviewer: Gilmara Moreira Oliveira

FACEPE

Date of review: 30 April 2020

Published online:

(C) The Author(s) 2020 This is an Open Access article, distributed under the terms of the Creative Commons Attribution licence (http://creativecommons.org/licenses/by/4.0/), which permits unrestricted re-use, distribution, and reproduction in any medium, provided the original work is properly cited.

Conflict of interest statement. Reviewer declares none.

Comments to the Author: Dear all The text is clearly written and well-designed. Also the the data is valid, presented clearly and ready to be published. I would like to offer just some simple suggestions:1. Figure 1: Insert identification (e.g. A and B).2. References with three or more authors should be quoted with the first author followed by et al. in italic.

\section{Score Card}

Presentation

Is the article written in clear and proper English? (30\%)

Is the data presented in the most useful manner? (40\%)

Does the paper cite relevant and related articles appropriately? (30\%)

Context

Does the title suitably represent the article? (25\%)

Does the abstract correctly embody the content of the article? (25\%)

Does the introduction give appropriate context? (25\%)

Is the objective of the experiment clearly defined? (25\%) 
Are the limitations of the experiment as well as the contributions of the experiment clearly outlined? (20\%) 


\section{Review 2: Salinity decreases transpiration of sorghum plants}

Reviewer: Dr. lug Lopes

Instituto Federal de Educação Ciência e Tecnologia Baiano, Agronomy, Salvador, Brazil, 41720-052

Date of review: 05 May 2020

Published online:

(C) The Author(s) 2020 This is an Open Access article, distributed under the terms of the Creative Commons Attribution licence (http://creativecommons.org/licenses/by/4.0/), which permits unrestricted re-use, distribution, and reproduction in any medium, provided the original work is properly cited.

Conflict of interest statement. None.

Comments to the Author: The manuscript has international relevance, as agricultural culture is widely used and there are large regions that present soil salinity problems. Corrections must be made for the purpose of presenting numerical and statistical results. Once these corrections have been made, the article has potential for publication. The article presents a good discussion and has scientific merit. The article must be accepted after corrections.

\section{Score Card}

Presentation

3.9

Is the article written in clear and proper English? (30\%)

Is the data presented in the most useful manner? (40\%)

Does the paper cite relevant and related articles appropriately? (30\%)

\section{Context}

Does the title suitably represent the article? (25\%)

Does the abstract correctly embody the content of the article? (25\%)

Does the introduction give appropriate context? (25\%)

Is the objective of the experiment clearly defined? (25\%)

Analysis

Does the discussion adequately interpret the results presented? (40\%)

Is the conclusion consistent with the results and discussion? (40\%)

Are the limitations of the experiment as well as the contributions of the experiment clearly outlined? (20\%) 


\section{Review 3: Salinity decreases transpiration of sorghum plants}

Reviewer: Dr. Jucicléia Soares da Silva

Empresa Brasileira de Pesquisa Agropecuária, Embrapa Semiárido, Rodovia BR-428, Km 152, s/n - Zona Rural , Petrolina, Pernambuco, Brazil, 56302-970

Date of review: 08 May 2020

Published online:

(C) The Author(s) 2020 This is an Open Access article, distributed under the terms of the Creative Commons Attribution licence (http://creativecommons.org/licenses/by/4.0/), which permits unrestricted re-use, distribution, and reproduction in any medium, provided the original work is properly cited.

Conflict of interest statement. Reviewer declares none.

Comments to the Author: Artigo de grande relevância cientifica.

\section{Score Card}

Presentation

Is the article written in clear and proper English? (30\%)

Is the data presented in the most useful manner? (40\%)

Does the paper cite relevant and related articles appropriately? (30\%)

Context

Does the abstract correctly embody the content of the article? (25\%)

Does the introduction give appropriate context? (25\%)

Is the objective of the experiment clearly defined? (25\%)

Analysis

Are the limitations of the experiment as well as the contributions of the experiment clearly outlined? (20\%) 